\title{
Antimicrobial Edible Film Prepared from Bacterial Cellulose Nanofibers/Starch/Chitosan for a Food Packaging Alternative
}

\author{
Hairul Abral $\left(\mathbb{D},{ }^{1}\right.$ Angga Bahri Pratama ${ }^{(D)},{ }^{2}$ Dian Handayani $\left(\mathbb{D},{ }^{3}\right.$ Melbi Mahardika $\left(\mathbb{D},{ }^{4}\right.$ \\ Ibtisamatul Aminah $\left({ }^{3},{ }^{3}\right.$ Neny Sandrawati $\odot{ }^{3}$ Eni Sugiarti, ${ }^{5}$ Ahmad Novi Muslimin $\odot{ }^{5}$ \\ S. M. Sapuan $\mathbb{D}^{6}{ }^{6}$ and R. A. Ilyas $\mathbb{1}^{7}$ \\ ${ }^{1}$ Department of Mechanical Engineering, Andalas University, 25163 Padang Sumatera Barat, Indonesia \\ ${ }^{2}$ Program Studi Teknik Mesin, Universitas Dharma Andalas, 25000 Padang Sumatera Barat, Indonesia \\ ${ }^{3}$ Laboratory of Sumatran Biota/Faculty of Pharmacy, Andalas University, 25163 Padang, Sumatera Barat, Indonesia \\ ${ }^{4}$ Department of Biosystems Engineering, Institut Teknologi Sumatera, 35365 South Lampung, Indonesia \\ ${ }^{5}$ Laboratory of High-Temperature Coating, Research Center for Physics Indonesian Institute of Sciences (LIPI), Serpong, Indonesia \\ ${ }^{6}$ Department of Mechanical and Manufacturing Engineering, Faculty of Engineering, Universiti Putra Malaysia, \\ 43400 UPM Serdang, Selangor, Malaysia \\ ${ }^{7}$ School of Chemical and Energy Engineering, Faculty of Engineering, Universiti Teknologi Malaysia, 81310 Skudai, Johor Bahru, \\ Johor, Malaysia
}

Correspondence should be addressed to Hairul Abral; habral@yahoo.com

Received 2 January 2021; Revised 9 March 2021; Accepted 15 March 2021; Published 1 April 2021

Academic Editor: Victor H. Perez

Copyright (c) 2021 Hairul Abral et al. This is an open access article distributed under the Creative Commons Attribution License, which permits unrestricted use, distribution, and reproduction in any medium, provided the original work is properly cited.

\begin{abstract}
As a contribution to the growing demand for environmentally friendly food packaging films, this work produced and characterized a biocomposite of disintegrated bacterial cellulose (BC) nanofibers and tapioca starch/chitosan-based films. Ultrasonication dispersed all fillers throughout the film homogeneously. The highest fraction of dried BC nanofibers $(0.136 \mathrm{~g})$ in the film resulted in the maximum tensile strength of $4.7 \mathrm{MPa} .0 .136 \mathrm{~g}$ BC nanofiber addition to the tapioca starch/chitosan matrix increased the thermal resistance (the temperature of maximum decomposition rate from 307 to $317^{\circ} \mathrm{C}$ ), moisture resistance (after $8 \mathrm{~h}$ ) by $8.9 \%$, and water vapor barrier $(24 \mathrm{~h}$ ) by $27 \%$. All chitosan-based films displayed antibacterial activity. This characterization suggests that this environmentally friendly edible biocomposite film is a potential candidate for applications in food packaging.
\end{abstract}

\section{Introduction}

The demand for affordable environmentally friendly plastic substitutes made from renewable sources continues to increase resulting in a growing interest in the research community in plant-based replacements for nondegradable plastics [1-3]. For the food packaging industry, promising cheap and abundant eco-friendly edible film-forming materials include starches, pure bacterial cellulose nanofibers, and chitosan [4]. However, films made of starch alone have low mechanical and thermal properties, high moisture absorption, and poor antimicrobial resistance $[5,6]$. Many attempts have been conducted previously to reduce these weaknesses by adding environmentally friendly fillers to the starch film [7-10]. Of these edible fillers, cellulose fiber and chitosan have significant potential, with one being one of the most abundant in nature[10,11]. Cellulose fiber has good mechanical properties and flexibility but no antimicrobial activity [12]. The tensile and thermal properties of the starch film were improved after reinforcement with randomly oriented cellulose fibers from kenaf [13], water hyacinth [14], and softwood [15]. However, these short cellulose nanofiber preparation methods tend to use potentially harmful chemicals and result in a high residue of hemicellulose, lignin, or other impurities. Nanofiber from bacterial cellulose pellicle has none of these disadvantages because it consists of large 
amounts of pure cellulose fibers with nanosized diameters [16]. Short BC nanofibers can be prepared from this pellicle using a high-shear homogenizer with a rotating blade to disintegrate the long fibers into nanosized lengths [17]. Recently, previous work has reported the interesting results that the microbial activity of the disintegrated $\mathrm{BC} /$ chitosan film was less than that of the BC sheet/chitosan one [1].

Chitosan has several advantages including antimicrobial activity, controlled release of food ingredients and drugs, relatively low cost, and widespread availability from a stable renewable source $[5,18]$. Numerous studies have been performed on the development of edible biocomposite films made from chitosan, cellulose, and starch $[19,20]$. Of course, as a food packaging material, this polysaccharide-based edible film should protect foods against deterioration due to microorganisms, moisture, dust, odors, and mechanical forces [21, 22]. There have been many previous studies reporting on the improved properties of the biocomposite film. However, characterizations of chitosan and disintegrated BC nanofiber content on tapioca starch-based biocomposites' properties have yet to be reported. This study understands the effect of the addition of both chitosan and disintegrated nanofiber from BC pellicle on the properties of this edible biocomposite film more completely. All samples were characterized by field emission scanning electron microscopy (FESEM), X-ray diffraction (XRD), Fourier transform infrared (FTIR), and thermogravimetric analysis (TGA). Opacity, moisture absorption (MA), water vapor permeability (WVP), and tensile properties were also measured.

\section{Materials and Experiment}

2.1. Materials. Local (Padang, Indonesia) commercially available tapioca starch (Cap Pak Tani brand) was washed once with distilled water to obtain pure tapioca starch. The pure wet starch was dried using a drying oven (Universal Oven Memmert UN-55) for $20 \mathrm{~h}$ at $50^{\circ} \mathrm{C}$. The dried starch was filtered through a $63 \mu \mathrm{m}$ mesh cloth. The chemical composition of dry starch granules was analyzed according to a previous amylopectin method [23]. The pure dried granular starch for this present work contained 14.5\% of amylose and $85.5 \%$ of glycerol (Brataco brand) purchased from Brataco (Padang, Indonesia) and chitosan (degree of deacetylation: 94\%) from CV. Chi Multiguna (Indramayu, Indonesia). Acetic acid $\left(\mathrm{CH}_{3} \mathrm{COOH}, 5 \%\right)$ was used as the solvent for chitosan.

2.2. Preparation of Single BC Nanofiber and Films. Single BC nanofiber was isolated and characterized as in our previous work [24]. Briefly, a wet pellicle with a dimension $(248 \times 151 \times 22 \mathrm{~mm})$ was purchased from a local smallscale industry in Padang, Indonesia. This pellicle, which is a common addition to drinks or desserts in the form of nata de coco, is the result of a week-long fermentation of coconut water, glucose, and acetic acid with Acetobacter xylinum in a static closed container. Integration of the pellicle was carried out with a homogenizer and ultrasonication probe. The crystallinity index of the disintegrated $\mathrm{BC}$ nanofiber was about $71 \%$. Figure 1 displays the steps of sample preparation from raw BC until biocomposite. The film sample was prepared as follows:

Starch film. About $10 \mathrm{~g}$ purified tapioca granules, $100 \mathrm{~mL}$ distilled water, and $2 \mathrm{~mL}$ glycerol were mixed in a glass beaker $(250 \mathrm{~mL})$ using a hot plate stirrer (Daihan Scientific $\mathrm{MSH}-200)$ at $500 \mathrm{rpm}$ and $65^{\circ} \mathrm{C}$ until completely gelatinized. The gel suspension was sonicated using an ultrasonic cell crusher (SJIA-1200W) at $600 \mathrm{~W}$ for $1 \mathrm{~min}$, then poured onto a petri dish $(d=145 \mathrm{~mm})$ and dried in a drying oven (Memmert Germany, Model $55 \mathrm{UN}$ ) at $50^{\circ} \mathrm{C}$ for $20 \mathrm{~h}$.

Chitosan film. Simultaneously, a mixture of $2.5 \mathrm{~g}$ chitosan and $100 \mathrm{~mL}$ acetic acid was prepared in a glass beaker $(250 \mathrm{~mL})$ and heated using a hot plate stirrer at $80^{\circ} \mathrm{C}$ for 2 hours until gelatinization. The chitosan gel was filtered using $74 \mu \mathrm{m}$ cheesecloth. The gel was poured onto a petri dish which was dried using the drying oven at $50^{\circ} \mathrm{C}$ for $20 \mathrm{~h}$.

Starch/chitosan film. The two gels, starch and chitosan, were blended in the ratio of $80: 20$ (70 g total weight) using an ultrasonic cell crusher at $600 \mathrm{~W}$ for 1 min keeping the temperature below $65^{\circ} \mathrm{C}$. The gel was poured onto a petri dish for drying as described in the starch sample preparation.

Biocomposite film. The blended starch/chitosan gels were mixed with the appropriate BC suspension $(10,15$, or $20 \mathrm{~mL})$. Each gel suspension was sonicated at $600 \mathrm{~W}$ for $1 \mathrm{~min}$, then cast onto a petri dish and dried in the drying oven at $50^{\circ} \mathrm{C}$ for $20 \mathrm{~h}$.

Abbreviations used for the studied samples with their compositions are shown in Table 1.

\subsection{Characterization}

2.3.1. FESEM Morphology of the Fracture Surface. The tensile sample's fracture surface morphology after the tensile test was observed using JIB-4610F FESEM from JEOL (Tokyo, Japan). At about $25 \mathrm{~mm}$ from its fracture surface, the tensile specimen was cut using a steel scissor (in perpendicular tensile direction) and placed on a specimen holder. All samples were coated with gold $(\mathrm{Au})$. An accelerating voltage of $10 \mathrm{kV}$ with $8 \mathrm{~mA}$ was set up for testing.

2.3.2. X-Ray Diffraction. The XRD pattern was recorded using an X'Pert PRO PANalytical instrument (Philips Analytical, Netherlands) with $\mathrm{CuK} \alpha$ radiation $(\lambda=0.154)$ at $40 \mathrm{kV}$ and $30 \mathrm{~mA}$. The scanning range was $5^{\circ}$ to $50^{\circ}$. The crystallinity index (CI) of the biocomposites was calculated using

$$
\mathrm{CI}=\left[\frac{\left(I_{002}-I_{\mathrm{am}}\right)}{I_{002}}\right] \times 100,
$$

where $I_{002}$ and $I_{\mathrm{am}}$ are the peak intensities of crystalline and amorphous regions, respectively [25].

2.3.3. Opacity Measurement. The opacity of the film was measured using a UV-Vis spectrophotometer (Shimadzu UV 1800 , Japan) in the range $400-800 \mathrm{~nm}$ according to ASTM D 1003-00 (Standard Test Method for Haze and Luminous Transmittance of Transparent Plastics). Films of $0.38 \mathrm{~mm}$ thickness were cut into $10 \mathrm{~mm} \times 25 \mathrm{~mm}$ rectangles. The opacity measurement was repeated 3 times. 


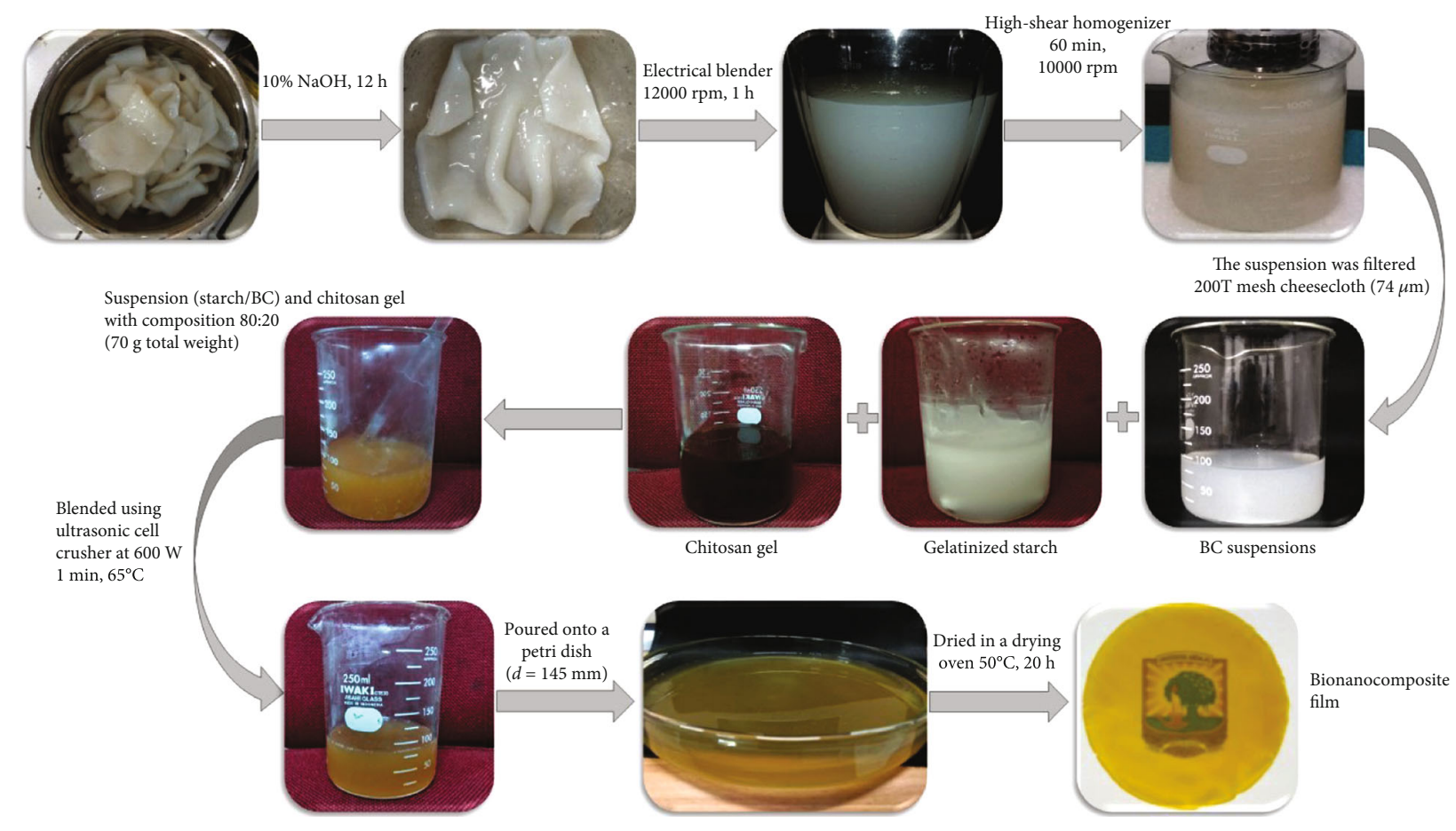

FIgURE 1: Steps of sample preparations for biocomposite.

TABLe 1: Composition of the starch film, chitosan film, and biocomposite films used in the study.

\begin{tabular}{|c|c|c|c|c|c|c|c|}
\hline Sample code & $\begin{array}{c}\text { Tapioca starch } \\
(\mathrm{g})\end{array}$ & $\begin{array}{l}\text { Nanofiber suspension } \\
(\mathrm{mL})\end{array}$ & $\begin{array}{c}\text { Dried nanofibers } \\
(\mathrm{g})\end{array}$ & $\begin{array}{l}\text { Aquades } \\
(\mathrm{mL})\end{array}$ & $\begin{array}{l}\text { Glycerol } \\
(\mathrm{mL})\end{array}$ & $\begin{array}{c}\text { Chitosan } \\
\text { (g) }\end{array}$ & $\begin{array}{l}\text { Acetic acid } \\
\quad(\mathrm{mL})\end{array}$ \\
\hline $\mathrm{GU}$ & 10 & - & - & 100 & 2 & - & - \\
\hline $\mathrm{CH}$ & - & - & - & - & - & 2.5 & 100 \\
\hline GU/CH & 10 & - & - & 100 & 2 & 2.5 & 100 \\
\hline $\mathrm{GU} / \mathrm{CH} / 10 \mathrm{BC}$ & 10 & 10 & 0.068 & 100 & 2 & 2.5 & 100 \\
\hline GU/CH/15BC & 10 & 15 & 0.102 & 100 & 2 & 2.5 & 100 \\
\hline $\mathrm{GU} / \mathrm{CH} / 20 \mathrm{BC}$ & 10 & 20 & 0.136 & 100 & 2 & 2.5 & 100 \\
\hline
\end{tabular}

2.3.4. Fourier Transform Infrared. FTIR spectra of films were recorded using a PerkinElmer FTIR spectrometer (Frontier Instrument, USA), equipped with deuterated triglycine sulfate, DTGS, detector, and extended range $\mathrm{KBr}$ beam splitter. This spectrometer was used in the frequency range in the wavenumber range of $4000-600 \mathrm{~cm}^{-1}$, at resolution $4 \mathrm{~cm}^{-1}$ with 32 scans per sample. Samples $(10 \mathrm{~mm} \times 10 \mathrm{~mm})$ were dried in the oven at $50^{\circ} \mathrm{C}$ until constant weight before characterization. The samples were made in powder and mixed with $\mathrm{KBr}$ as well as followed by the pressure within the pellet ultrathin layer [26].

2.3.5. Moisture Absorption and Water Vapor Permeability. Moisture absorption (MA). MA was determined using the method described in a previous study [27]. All biocomposite samples were dried in a drying oven (Memmert Germany, Model $55 \mathrm{UN}$ ) at $50^{\circ} \mathrm{C}$ until a constant weight was achieved. The dried sample was stored in a closed chamber with $75 \%$ $\mathrm{RH}$ at $25^{\circ} \mathrm{C}$. The samples were weighed every $30 \mathrm{~min}$ for $7 \mathrm{~h}$ with a precision balance (Kenko) with a $0.1 \mathrm{mg}$ accuracy. MA was calculated using

$$
\mathrm{MA}=\frac{\left(w_{\mathrm{h}}-w_{\mathrm{o}}\right)}{w_{\mathrm{o}}},
$$

where $w_{\mathrm{h}}$ is the final weight and $w_{\mathrm{o}}$ is the initial weight of the sample. MA determination was repeated 5 times for each film.

Water vapor permeability (WVP). WVP was measured according to the method described by previous work [28]. WVP determination was repeated 3 times for each film.

2.3.6. Thermogravimetric Analysis (TGA) and Derivative Thermogravimetry (DTG). TGA and DTG of all samples were characterized using a differential scanning calorimeter (Linseis TA type PT 1600, Germany). About $25 \mathrm{mg}$ of the film was positioned on the microbalance located inside the 


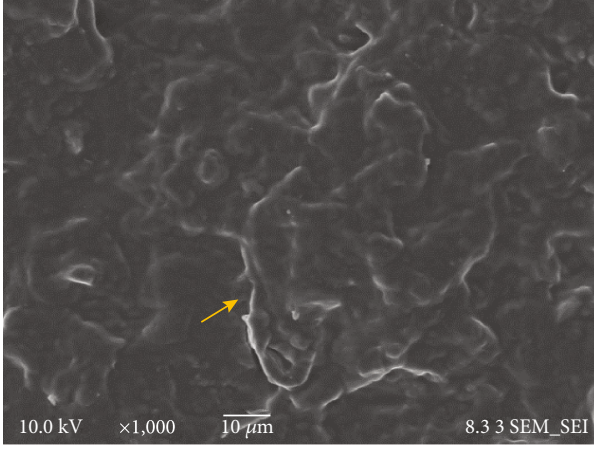

(a)
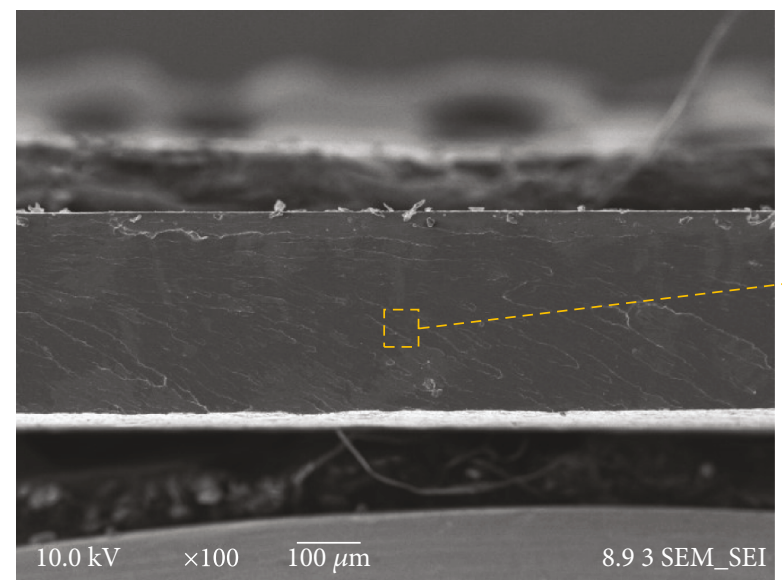

(c)

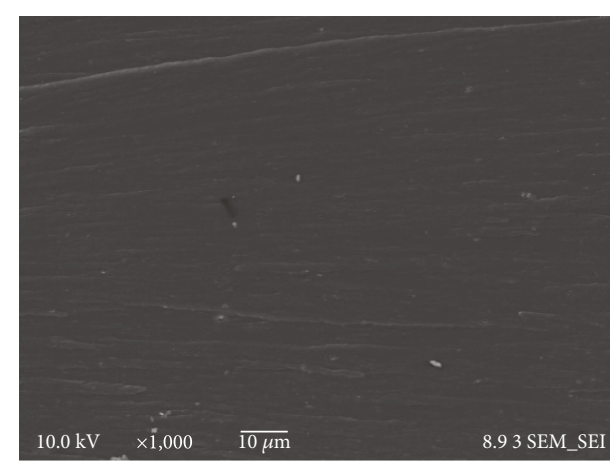

(b)
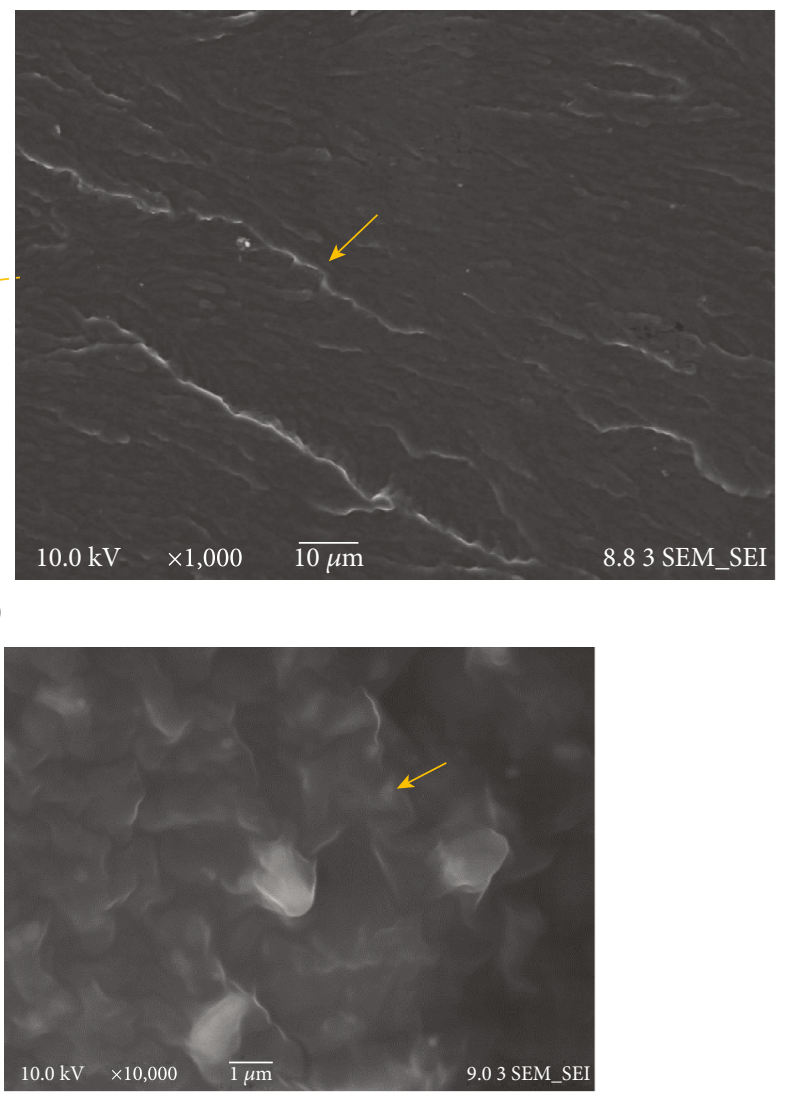

(e)

FIGURE 2: FESEM images of the fracture surface for the pure starch film (a), pure chitosan film (b), starch/chitosan film (c), GU/CH/15BC film (d), and GU/CH/20BC film (e).

furnace. The test was carried out from $35^{\circ} \mathrm{C}$ up to $550^{\circ} \mathrm{C}$ with a heating rate of $10^{\circ} \mathrm{C} / \mathrm{min}$ in a nitrogen atmosphere.

2.3.7. Tensile Properties. Tensile properties of the biocomposites, including tensile strength and elongation at break, were measured using COM-TEN 95T Series 5K (Pinellas Park, USA) and were performed according to the ASTM D 638 type $\mathrm{V}$ standard. Before the test, all samples were stored in a desiccator with $50 \pm 5 \%$ relative humidity at $25^{\circ} \mathrm{C}$ for $48 \mathrm{~h}$. Samples were then tested at room temperature and $\mathrm{RH} 75 \%$ using a tensile test speed of $5 \mathrm{~mm} / \mathrm{min}$. The testing of the film was repeated at least three times for each fiber content.
2.3.8. Antimicrobial Activity. The antibacterial activity of the starch/chitosan-based biocomposite films was assayed using the agar diffusion method (Bauer, Kirby, Sherris, and Turck, 1966). Four microbe strains were used: Gram-positive Staphylococcus aureus and Bacillus subtilis bacteria and Gramnegative Escherichia coli and Pseudomonas aeruginosa. The microbial suspensions in saline solution $(\mathrm{NaCl} 0.85 \%$ sterile) were standardized using the McFarland scale to inoculate petri dishes containing nutrient agar for bacteria. $6 \mathrm{~mm}$ film diameter disks were placed on the inoculated agar then incubated at $30^{\circ} \mathrm{C}$ for $24 \mathrm{~h}$. The diameter of the growth inhibition zones around the film disks was gauged visually. All tests 


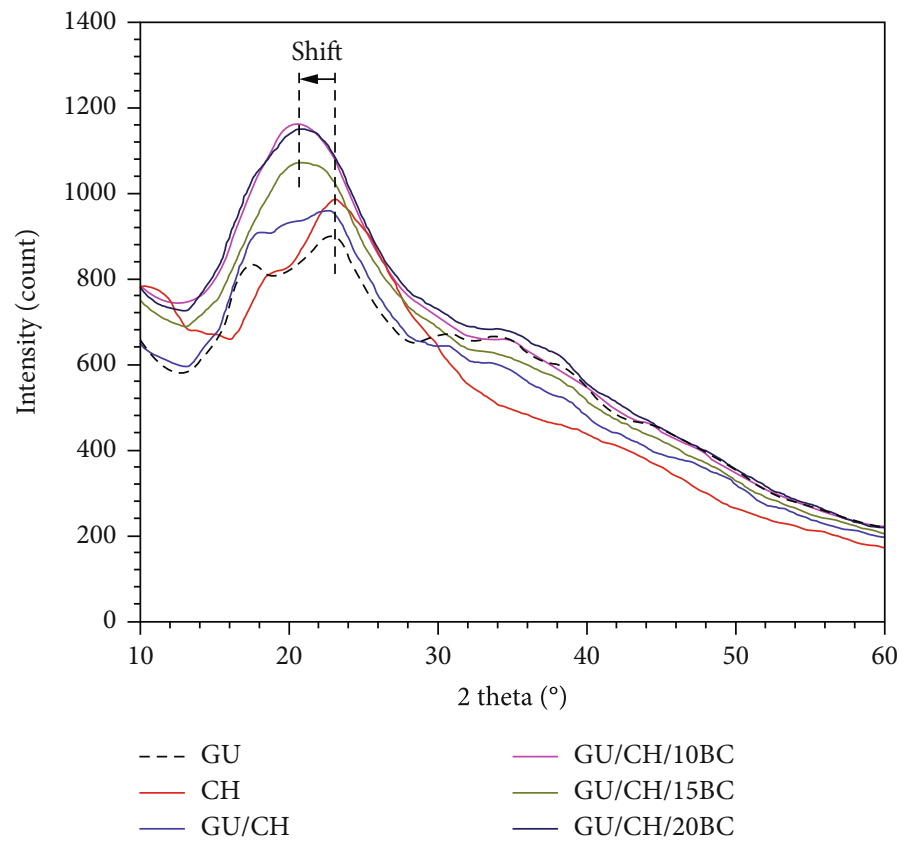

FIgURE 3: The XRD patterns of all samples.

TABLE 2: Crystallinity index, opacity value, and thermal properties of all samples.

\begin{tabular}{lccc}
\hline Films & Crystallinity index $(\%)$ & Opacity $(\mathrm{AUnm})^{*}$ & Maximum decomposition temperature $\left({ }^{\circ} \mathrm{C}\right)$ \\
\hline $\mathrm{GU}$ & 11 & $280.5 \pm 0.16^{\mathrm{d}}$ & 268 \\
$\mathrm{CH}$ & 17 & $450.8 \pm 0.04^{\mathrm{f}}$ & 311 \\
$\mathrm{GU} / \mathrm{CH}$ & 14 & $202.3 \pm 0.98^{\mathrm{a}}$ & 307 \\
$\mathrm{GU} / \mathrm{CH} / 10 \mathrm{BC}$ & 35 & $208.1 \pm 1.09^{\mathrm{b}}$ & 313 \\
$\mathrm{GU} / \mathrm{CH} / 15 \mathrm{BC}$ & 36 & $237.9 \pm 0.63^{\mathrm{c}}$ & 314 \\
$\mathrm{GU} / \mathrm{CH} / 20 \mathrm{BC}$ & 37 & $328.3 \pm 0.76^{\mathrm{e}}$ & 317 \\
\hline
\end{tabular}

${ }^{*}$ Different letters $\mathrm{a}, \mathrm{b}, \mathrm{c}, \mathrm{d}, \mathrm{e}$, and $\mathrm{f}$ in the same column indicate significant differences in means $(p \leq 0.05)$.

were carried out in triplicate, and the antibacterial activity was expressed as the mean of the inhibition diameters $(\mathrm{mm})$.

2.3.9. Statistical Analysis. Experimental data were analyzed using IBM SPSS Statistics 25.0 (IBM Corporation, Chicago, USA). One-way analysis of variance (ANOVA) and a $p$ test were used to identify the significance of any effects of varying nanofiber content on properties of the biocomposites. Duncan's multiple range tests were used on the MA and WVP results using a $95 \%(p \leq 0.05)$ confidence level.

\section{Results and Discussion}

3.1. Morphological Biocomposites. Figure 2 displays FESEM fracture surface micrographs for the pure starch film (a), pure chitosan film (b), starch/chitosan film (c), GU/CH/15BC film (d), and GU/CH/20BC film (e). The surface of the starch film was rough (Figure 2(a)) probably as a result of a long tortuous way of the polymer chains looking for the weak section of the chain structure. Meanwhile, the $\mathrm{CH}$ film had a smooth fracture surface (Figure 2(b)) attributed to unimpeded crack propagation and corresponding to its brittle properties.

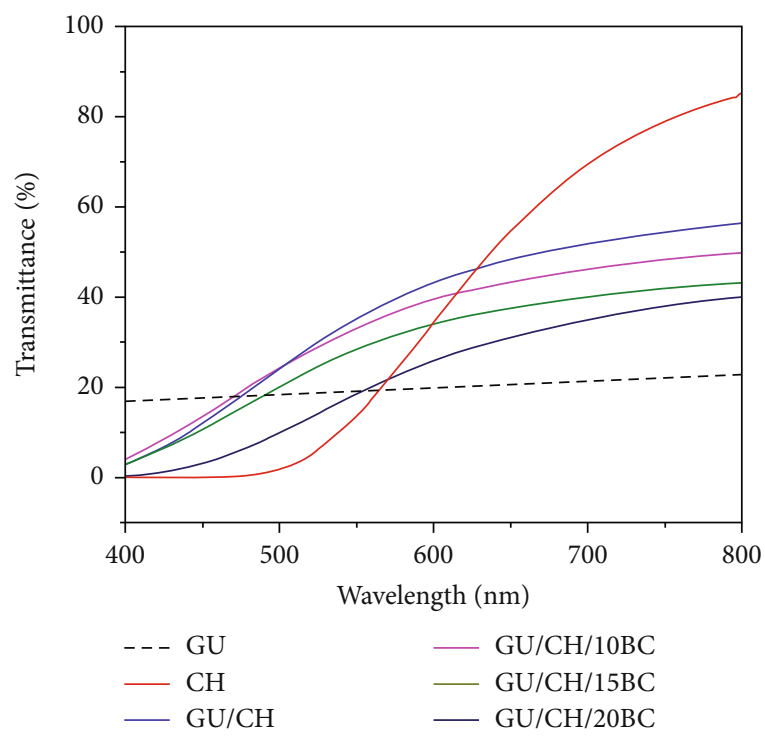

FIgURE 4: The transmittance of all samples. 


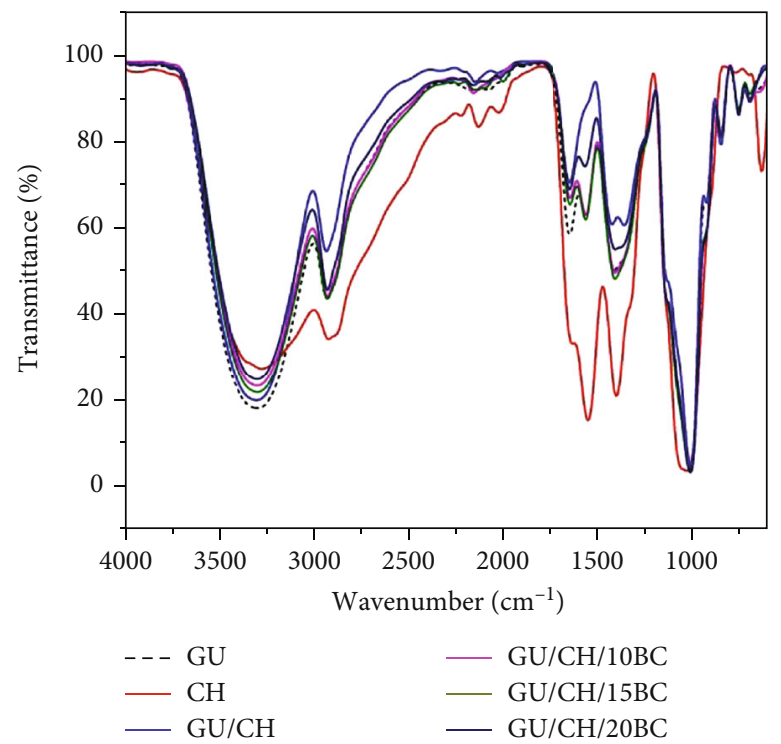

(a)

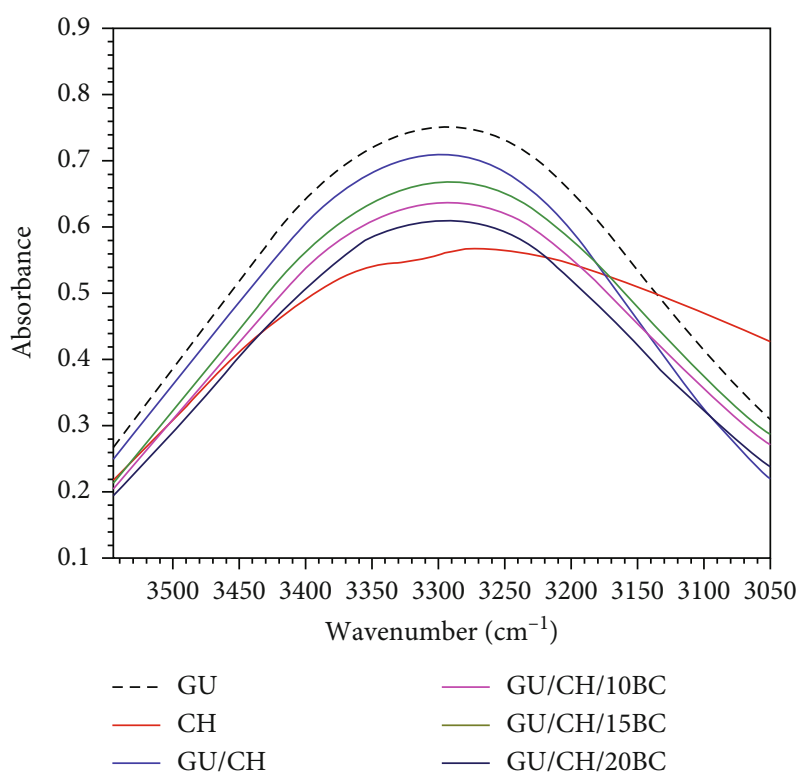

(b)

FiguRE 5: FTIR spectrum resulting from triplicate measurements of each film. The full spectrum from 4000 to $250 \mathrm{~cm}^{-1}$ (a). Sections of the spectrum for $\mathrm{O}-\mathrm{H}$ stretching vibration (b).

Figure 2(c) displays the GU/CH fracture surface, which was rougher than the $\mathrm{CH}$ sample. The different chemical structures of both these substances produce a weaker structural section in which the crack propagates with a longer tortuous way resulting in microscopic features known as a beach mark as shown by the yellow arrow in the inset of Figure 2(c) which marks an interruption of the cracking progress. Adding BC into the blends continuously increases the surface roughness of the biocomposite (yellow arrow in Figures 2(d) and 2(e)). In these figures, disintegrated $\mathrm{BC}$ nanofibers were dispersed homogeneously after ultrasonication. A similar result also is supported by previous studies $[14,17,24,29,30]$.

3.2. X-Ray Diffraction. The X-ray diffraction curves for all studied films are shown in Figure 3. All films show a similar semicrystalline pattern with prominent peaks at about $2 \theta=$ $20^{\circ}$ and $23^{\circ}$. The crystallinity index (CI) of each sample is shown in Table 2. The GU/CH blend film has a CI value of $14 \%$ between the CI of chitosan (17\%) and the CI of the starch film (11\%). The addition of any fraction of nanofibers to the starch-based matrix improves the CI value of the biocomposite films (around 164\% increase compared to $\mathrm{GU} / \mathrm{CH}$ ). This increased value indicates better filler dispersion in the starch matrix thanks to ultrasonication [2]. Samples before mixing with nanofibers display the main peak position at $2 \theta=23^{\circ}$. The addition of the nanofibers shifted the position toward the left side $\left(2 \theta=20^{\circ}\right)$. According to previous work, shifting the peak position to the left side can be associated with an increase in tensile residual stress resulting from increases in the polymer chains' interlayer spacing [31].

3.3. Transparency. In food packaging applications, high transparency can be an essential property [32]. The transparency values for all samples are displayed in Figure 4. The GU film displays low transmittance at all wavelengths. The high- est transparency at $800 \mathrm{~nm}$ belongs to the $\mathrm{CH}$ film. Therefore, after mixing starch with chitosan, the $\mathrm{GU} / \mathrm{CH}$ film became more transparent. However, the BC nanofiber addition to this $\mathrm{GU} / \mathrm{CH}$ film significantly decreased $(p \leq 0.05)$ the transparency of the biocomposite film. This phenomenon is because increasing amounts of the nanofiber increase the amount of reflected light in the film. The lowest transparency was consequently measured on the film with the highest fiber loading, the GU/CH/20BC film (28.9\% less than the GU/CH film). This value still agrees with previous work [33]. Despite the decreasing transparency, this film was still clear enough to see through easily. The consistency of transparency readings in each of the repeats for each fiber loading, as shown by the small standard deviation values, confirms that the cellulose fibers are homogeneously dispersed in the starchbased matrix. This result is consistent with Figure 2(e) which shows beach marks spread evenly on all fracture surfaces of the biocomposite film.

3.4. FTIR Spectra. Structural changes in the starch-based film after mixing with chitosan or/and nanofibers can be observed using an FTIR curve. Figure 5 displays an FTIR curve of the mean transmittance values for three samples of each biocomposite. Shifts of peak intensity, broadening of absorption peaks, and appearance of new bands in the FTIR spectra correspond to structural changes [34]. There are absorption peaks in the GU film at about $3247 \mathrm{~cm}^{-1}$ (-OH stretching) and $2917 \mathrm{~cm}^{-1}$ due to $\mathrm{CH}$ stretching. The band at $1650 \mathrm{~cm}^{-1}$ is present due to the deformation vibration of the absorbed water molecules. The characteristic absorption peak of chitosan is the band at $1559 \mathrm{~cm}^{-1}$, which is assigned to the stretching vibration of the amino group of chitosan. Another band at $3367 \mathrm{~cm}^{-1}$ is due to amine $\mathrm{NH}$ symmetric vibration. The wavenumber and $T$ value of $\mathrm{O}-\mathrm{H}$ stretching shift from 


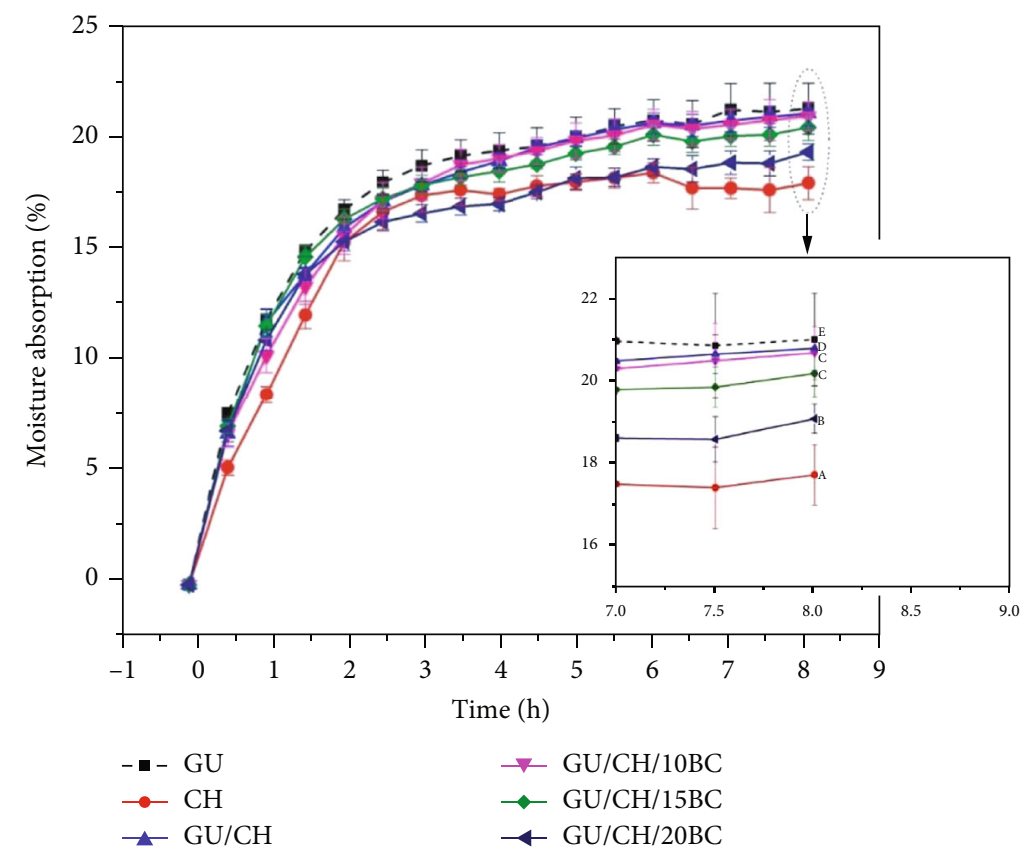

(a)

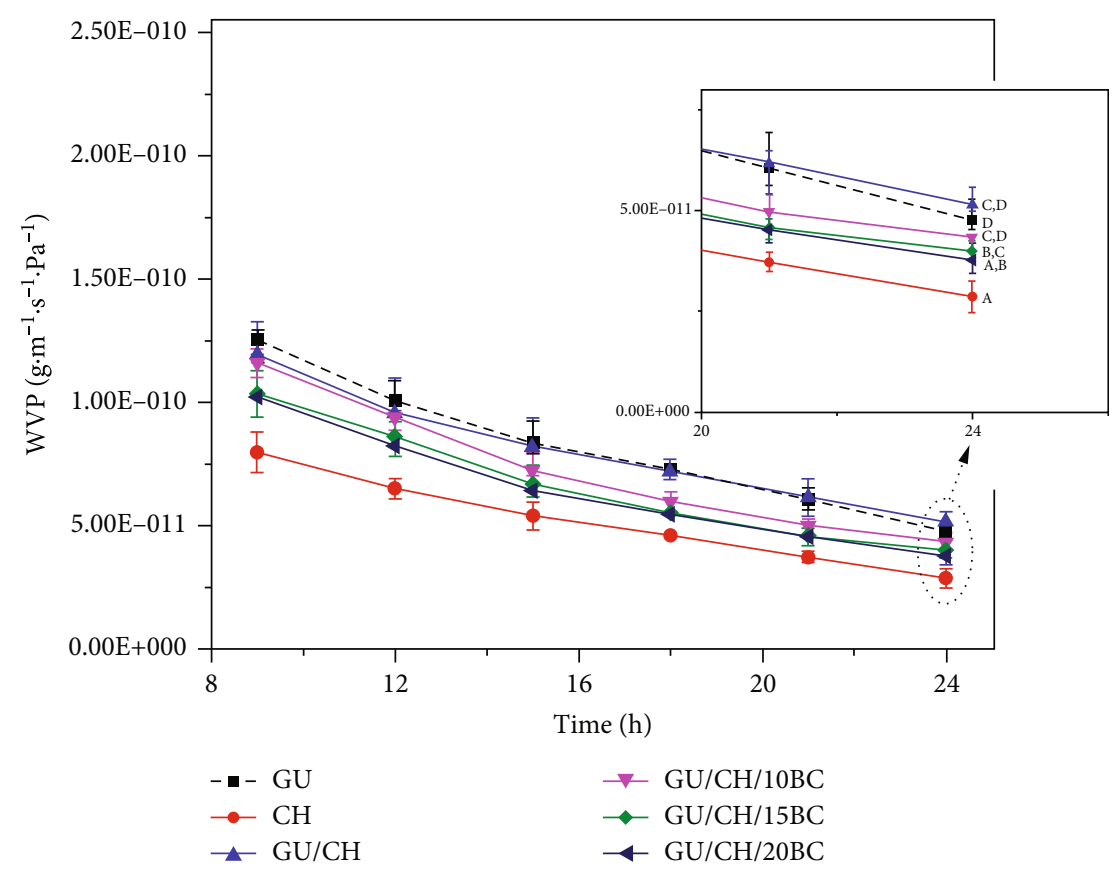

(b)

Figure 6: Average value of moisture absorption (a) and WVP (b) of each studied film. Different letters a, b, c, d, and e in the inset indicate significant differences $(p \leq 0.05)$.

$3290 \mathrm{~cm}^{-1}$ and $17.9 \%$ for the GU film to $3288 \mathrm{~cm}^{-1}$ and $19.6 \%$ for the GU/CH blend film. Similar shifting was also observed on the GU/CH-based biocomposite film due to the presence of nanofibers. For example, $T$ of the GU/CH film at about $3290 \mathrm{~cm}^{-1}$ is $19.6 \%$ but $24.5 \%$ for the $\mathrm{GU} / \mathrm{CH} / 20 \mathrm{BC}$ film. As expected, increasing concentrations of BC increased the peak $T$ and shifted the wavenumber of $\mathrm{O}-\mathrm{H}$ functional groups. This case is probably a result of increasing hydrogen bonds between starch and/or nanofiber polymer chains and amino functional groups [35].

3.5. Moisture Absorption and Water Vapor Permeability. Figure 6(a) shows the moisture absorption (MA) of the pure starch film, chitosan film, and starch/chitosan-based biocomposite film. The pure chitosan film has the lowest MA $(17.7 \%$ after $8 \mathrm{~h}$ in the humid chamber). The presence of nanofibers 


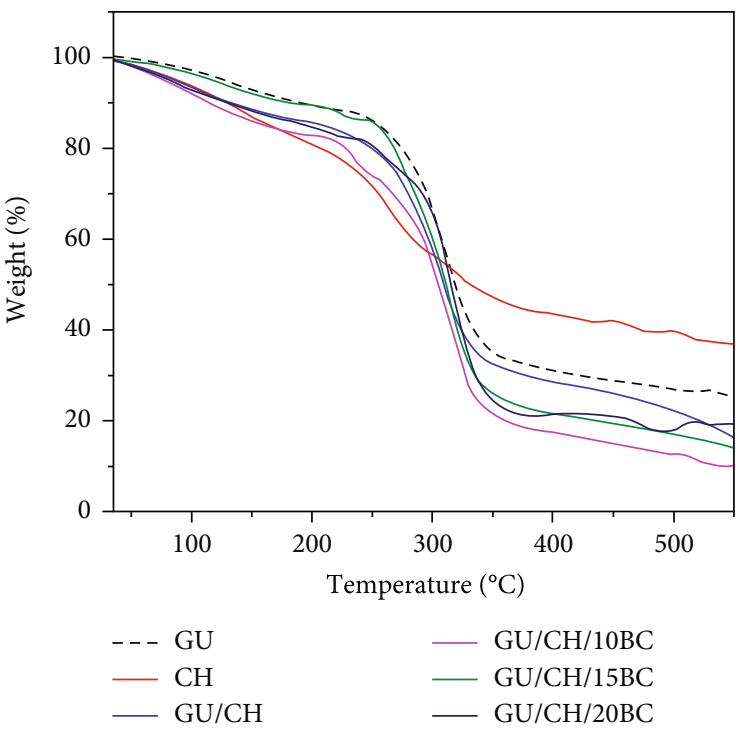

(a)

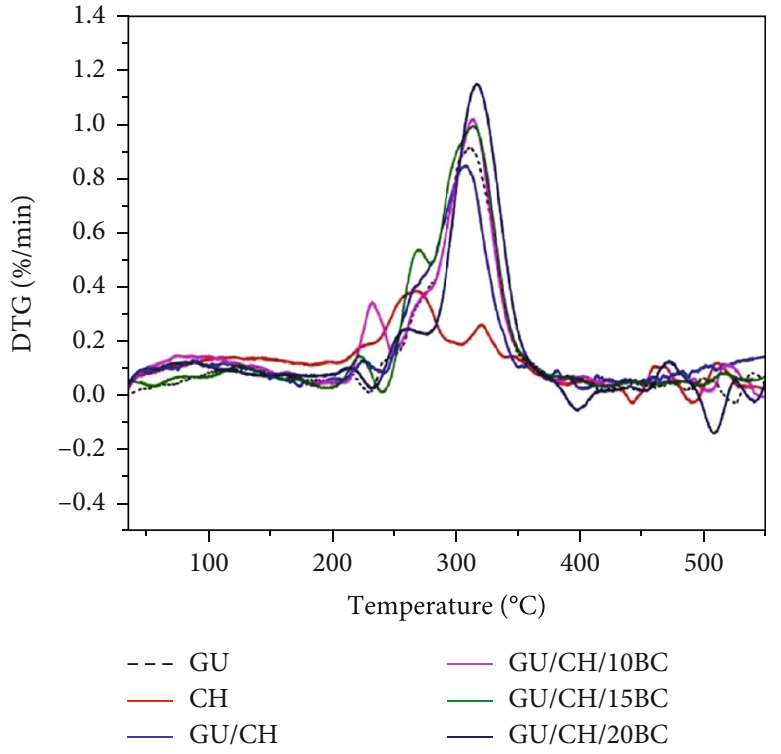

(b)

FIgUre 7: TGA (a) and DTG (b) charts of all samples.

in the starch/chitosan-based film results in a decrease in MA of the biocomposites. Higher nanofiber loading leads to lower average MA values. This result is because nanofiber and chitosan are more hydrophobic than the neat starch film. Dispersion of fillers in the starch film homogeneously results in decreasing MA of the biocomposite film. Better intermolecular hydrogen bonding between the starch matrix and the chitosan and fiber improves the moisture resistance of the biocomposite film due to reducing the number of free hydroxyl groups. This result is consistent with the FTIR pattern (Figure 5) showing the weakest intensity of $\mathrm{O}-\mathrm{H}$ stretching and $\mathrm{O}-\mathrm{H}$ of absorbed water peaks in the films with the highest nanofiber content due to the reduction in free hydroxyl groups. Similar findings of reducing moisture absorption with increased fiber loadings have also been reported previously [30]. Figure 5(b) shows water vapor permeability (WVP) of both starch and chitosan films and biocomposite films. As expected, the pattern of WVP with the addition of nanofibers is similar to that of MA. There is a decrease in the WVP value in films that contain more nanofibers. WVP of the GU/CH/20BC sample is $27 \%$ lower than that of the GU/CH film after $24 \mathrm{~h}$. The decrease in WVP is because moisture is absorbed less readily into the biocomposite for the reasons described above.

Also, well-dispersed nanofiber hinders the path for water molecule diffusion through the film due to the more compact, homogeneous polymer structures [29]. As shown in Figure 6, the WVP value of the GU/CH/20BC film is $3.7 \times$ $10^{-11} \mathrm{~g} \mathrm{~m}^{-1} \mathrm{~s}^{-1} \mathrm{~Pa}^{-1}(24 \mathrm{~h})$, similar to that found in a previous study on the improvement of the shelf life of yam starch/chitosan-coated apples [36]. Therefore, this film has a good potential for the shelf life of various food types.

3.6. Thermal Properties. Figures 7(a) and 7(b) show TGA and DTG curves of each tested film as a function of temperature. There are three stages of weight loss of the film shown in a
TGA graph. The first stage at $100-150^{\circ} \mathrm{C}$ is related to weight loss in the film due to the evaporation of the absorbed moisture. This small amount of dehydration is evident in the DTG curve (Figure 7(b)). The weight loss for the second stage at $250-350^{\circ} \mathrm{C}$ is attributed to the decomposition of starch, chitosan, and nanofibers. In the temperature range of $360-570^{\circ} \mathrm{C}$, a third weight loss was observed due to a final decomposition to ash. The temperature of the maximum decomposition rate $\left(T_{\mathrm{m}}\right)$ at the second stage was higher $\left(311^{\circ} \mathrm{C}\right)$ for starch than for chitosan $\left(268^{\circ} \mathrm{C}\right)$. As expected, the addition of chitosan to starch decreased the $T_{\mathrm{m}}$ value slightly $\left(307^{\circ} \mathrm{C}\right)$. However, the thermal resistance of the starch/chitosan-based film became higher with the addition of nanofibers (Figures 7(a) and 7(b)). For example, the $T_{\mathrm{m}}$ of the GU/CH film increased from $10^{\circ} \mathrm{C}$ to $317^{\circ} \mathrm{C}$ after adding dried nanofibers of $0.136 \mathrm{~g}$. This increased value is probably because of the higher crystallinity in the sample [30]. Also, the higher thermal resistance resulted from better interfacial hydrogen bonding between starch and nanofiber dispersed homogeneously $[17,30]$. This result is consistent with the high CI value of films with high nanofiber content, as shown in the XRD curve (Table 2).

3.7. Tensile Properties. Figure 8 shows the tensile properties of all tested samples. TS for the GU/CH film was $2.6 \mathrm{MPa}$, a value between pure $\mathrm{GU}(1.4 \mathrm{MPa})$ and $\mathrm{CH}(3.2 \mathrm{MPa})$. As expected, the nanofiber addition to the $\mathrm{GU} / \mathrm{CH}$ film led to an increase in its TS value. The maximum TS was $4.7 \mathrm{MPa}$, measured on the GU/CH/20BC film, reinforced with the highest fiber loading $(0.136 \mathrm{~g})$. This increased TS value probably results from the increased crystallinity index (Table 2), better nanofiber dispersion (Figure 2), and better interfacial hydrogen bonding between the nanofibers with the GU/CH matrix [20]. The pure chitosan film is the least brittle of all the films with an $\mathrm{EB}$ of only $0.98 \%$. After mixing the chitosan with starch, the EB of the GU/CH film became higher (11\%). 


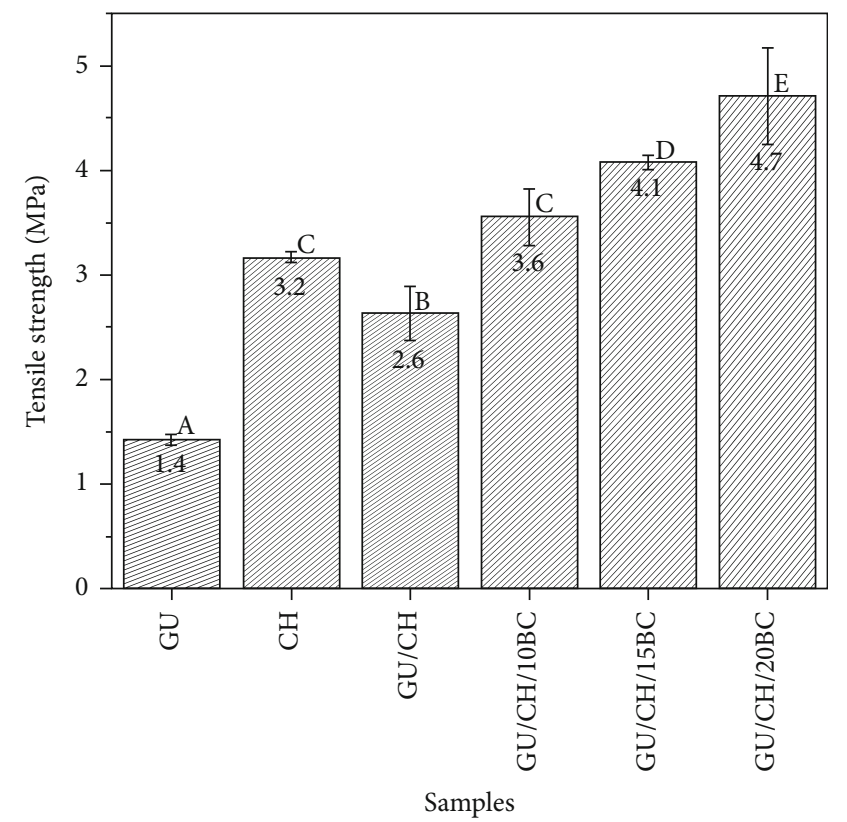

(a)

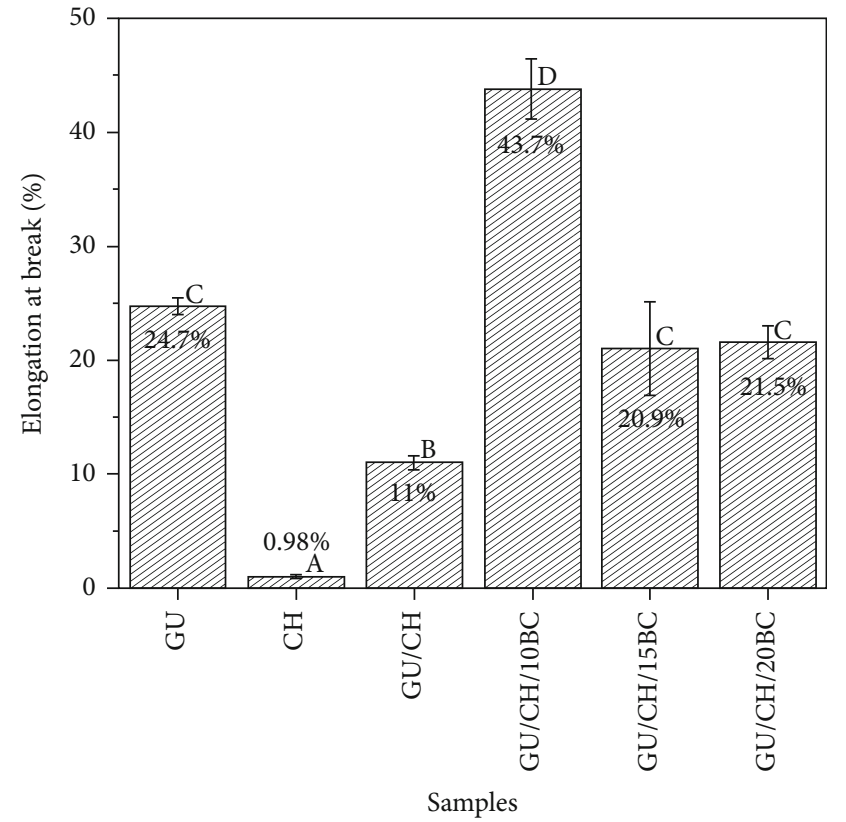

(b)

Figure 8: Tensile strength (a) and elongation at break (b) of each sample. Different letters a, b, c, d, and e in the vertical bar chart indicate significant differences $(p \leq 0.05)$.

TABLE 3: Antibacterial activity of the films.

\begin{tabular}{|c|c|c|c|c|}
\hline \multirow{2}{*}{ Films } & \multicolumn{4}{|c|}{ Diameter of inhibition zones $(\mathrm{mm})$ against microorganisms* } \\
\hline & SA & $\mathrm{BC}$ & EC & PA \\
\hline$\overline{\mathrm{CH}}$ & $20.9 \pm 1.9$ & $13.9 \pm 7.2$ & $12.8 \pm 0.2$ & $15.1 \pm 0.1$ \\
\hline GU & 0 & 0 & 0 & 0 \\
\hline $\mathrm{GU} / \mathrm{CH}$ & $18 \pm 1.6$ & $12.3 \pm 6.4$ & $12.3 \pm 6.9$ & $12.0 \pm 3.5$ \\
\hline GU/CH/10BC & $14.7 \pm 6$ & $11.9 \pm 6.1$ & $11.4 \pm 5.5$ & $11.3 \pm 6.5$ \\
\hline GU/CH/15BC & $12.1 \pm 7.2$ & $10.5 \pm 4.2$ & $12.5 \pm 2.5$ & $10.3 \pm 3.9$ \\
\hline GU/CH/20BC & $14.5 \pm 5.8$ & $10.6 \pm 4.9$ & $10.3 \pm 1.5$ & $13.4 \pm 3.3$ \\
\hline BC nanofibers & 0 & 0 & 0 & 0 \\
\hline
\end{tabular}

${ }^{*} \mathrm{SA}=$ Staphylococcus aureus $; \mathrm{BC}=$ Bacillus subtilis $; \mathrm{EC}=$ Escherichia coli PA = Pseudomonas aeruginosa .

Even the addition of the BC nanofibers to the GU/CH film improved its EB. This tendency is attributable to longer tortuous pathways of the crack propagation through the matrix due to the $\mathrm{BC}$ nanofibers. Further nanofiber loading did not result in statistically significant changes in EB of the biocomposite film.

3.8. Antibacterial Activity. Table 3 displays the diameters of antibacterial activity inhibition zones against all microorganisms tested in studied samples. BC nanofibers did not inhibit any microorganisms. This phenomenon is in good agreement with previous work [37]. A similar appearance was also displayed by the GU film without antibacterial activity. However, all chitosan-contained films were effective against Gram-positive bacteria and Gram-negative bacteria. This result could be due to the numerous active ingredients present in chitosan. Chitosan could adsorb the electronegative substance in the cell, and it disturbs the physiological activities of the bacteria and kills them [38].

\section{Conclusion}

This work characterized a tapioca starch/chitosan-based film reinforced by bacterial cellulose nanofiber. All chitosanbased films had antibacterial activity. $0.136 \mathrm{~g}$ nanofiber addition to this film led to the highest tensile strength and the highest thermal resistance. The presence of nanofibers increased moisture resistance and water barrier properties. The addition of the nanofibers led to a decrease in transparency. However, the resulting translucent biocomposite film could still be seen through clearly. Overall, this biocomposite film could become a food packaging alternative for replacing hydrocarbon-based plastics. 


\section{Data Availability}

We have data supporting the results of this work. The Microsoft Word document data used to support the findings of this study are available from the corresponding author upon request. Please email habral@yahoo.com.

\section{Conflicts of Interest}

We affirm that there is no conflict of interest.

\section{Acknowledgments}

Acknowledgment is addressed to Universitas Andalas for supporting research funding with project name PDU KRP1GB UNAND (number T/5/UN.16.17/PT.01.03/ISPDU-KRP1GB/2020).

\section{References}

[1] I. Dinika, D. K. Verma, R. Balia, G. L. Utama, and A. R. Patel, "Potential of cheese whey bioactive proteins and peptides in the development of antimicrobial edible film composite: a review of recent trends," Trends in Food Science and Technology, vol. 103, pp. 57-67, 2020.

[2] M. Asrofi, H. Abral, A. Kasim, A. Pratoto, M. Mahardika, and F. Hafizulhaq, "Characterization of the sonicated yam bean starch bionanocomposites reinforced by nanocellulose water hyacinth fiber (Whf): the effect of various fiber loading," Journal of Engineering Science and Technology, vol. 13, pp. 27002715, 2018.

[3] H. Abral, G. J. Putra, M. Asrofi, J. Park, and H. Kim, "Effect of vibration duration of high ultrasound applied to biocomposite while gelatinized on its properties," Ultrasonics Sonochemistry, vol. 40, no. Part A, pp. 697-702, 2018.

[4] I. Gan and W. S. Chow, "Antimicrobial poly(lactic acid)/cellulose bionanocomposite for food packaging application: a review," Food Packaging and Shelf Life, vol. 17, pp. 150-161, 2018.

[5] L. V. Cabañas-Romero, C. Valls, S. V. Valenzuela et al., "Bacterial cellulose-chitosan paper with antimicrobial and antioxidant activities," Biomacromolecules, vol. 21, no. 4, pp. 1568-1577, 2020.

[6] M. Babaee, M. Jonoobi, Y. Hamzeh, and A. Ashori, "Biodegradability and mechanical properties of reinforced starch nanocomposites using cellulose nanofibers," Carbohydrate Polymers, vol. 132, pp. 1-8, 2015.

[7] S. M. Noorbakhsh-Soltani, M. M. Zerafat, and S. Sabbaghi, "A comparative study of gelatin and starch-based nano-composite films modified by nano-cellulose and chitosan for food packaging applications," Carbohydrate Polymers, vol. 189, pp. 48-55, 2018.

[8] Z. Shariatinia and M. Fazli, "Mechanical properties and antibacterial activities of novel nanobiocomposite films of chitosan and starch," Food Hydrocolloids, vol. 46, pp. 112-124, 2015.

[9] S. Chillo, S. Flores, M. Mastromatteo, A. Conte, L. Gerschenson, and M. A. Del Nobile, "Influence of glycerol and chitosan on tapioca starch-based edible film properties," Journal of Food Engineering, vol. 88, no. 2, pp. 159-168, 2008.

[10] U. Qasim, A. I. Osman, A.'. H. al-Muhtaseb et al., "Renewable cellulosic nanocomposites for food packaging to avoid fossil fuel plastic pollution: a review," Environmental Chemistry Letters, vol. 19, no. 1, pp. 613-641, 2021.

[11] P. Cazón and M. Vázquez, "Mechanical and barrier properties of chitosan combined with other components as food packaging film," Environmental Chemistry Letters, vol. 18, no. 2, pp. 257-267, 2020.

[12] I. M. S. Araújo, R. R. Silva, G. Pacheco et al., "Hydrothermal synthesis of bacterial cellulose-copper oxide nanocomposites and evaluation of their antimicrobial activity," Carbohydrate Polymers, vol. 179, pp. 341-349, 2018.

[13] S. Y. Z. Zainuddin, I. Ahmad, H. Kargarzadeh, I. Abdullah, and A. Dufresne, "Potential of using multiscale kenaf fibers as reinforcing filler in cassava starch-kenaf biocomposites," Carbohydrate Polymers, vol. 92, no. 2, pp. 2299-2305, 2013.

[14] M. Asrofi, H. Abral, A. Kasim, A. Pratoto, M. Mahardika, and F. Hafizulhaq, "Mechanical properties of a water hyacinth nanofiber cellulose reinforced thermoplastic starch bionanocomposite: effect of ultrasonic vibration during processing," Fibers, vol. 6, no. 2, p. 40, 2018.

[15] C. M. O. Müller, J. B. Laurindo, and F. Yamashita, "Effect of cellulose fibers addition on the mechanical properties and water vapor barrier of starch-based films," Food Hydrocolloids, vol. 23, no. 5, pp. 1328-1333, 2009.

[16] H. Abral, V. Lawrensius, D. Handayani, and E. Sugiarti, "Preparation of nano-sized particles from bacterial cellulose using ultrasonication and their characterization," Carbohydrate Polymers, vol. 191, pp. 161-167, 2018.

[17] H. Abral, A. Hartono, F. Hafizulhaq, D. Handayani, E. Sugiarti, and O. Pradipta, "Characterization of PVA/cassava starch biocomposites fabricated with and without sonication using bacterial cellulose fiber loadings," Carbohydrate Polymers, vol. 206, pp. 593-601, 2018.

[18] T. Bourtoom and M. S. Chinnan, "Preparation and properties of rice starch-chitosan blend biodegradable film," LWT- Food Science and Technology, vol. 41, no. 9, pp. 1633-1641, 2008.

[19] M. M. Marvizadeh, N. Oladzadabbasabadi, A. Mohammadi Nafchi, and M. Jokar, "Preparation and characterization of bionanocomposite film based on tapioca starch/bovine gelatin/nanorod zinc oxide," International Journal of Biological Macromolecules, vol. 99, pp. 1-7, 2017.

[20] M. Mahardika, H. Abral, A. Kasim, S. Arief, F. Hafizulhaq, and M. Asrofi, "Properties of cellulose nanofiber/bengkoang starch bionanocomposites: effect of fiber loading," LWT-Food Science and Technology, vol. 116, article 108554, 2019.

[21] N. A. Al-Tayyar, A. M. Youssef, and R. Al-hindi, "Antimicrobial food packaging based on sustainable bio-based materials for reducing foodborne pathogens: a review," Food Chemistry, vol. 310, article 125915, 2020.

[22] S. Y. Sung, L. T. Sin, T. T. Tee et al., "Antimicrobial agents for food packaging applications," Trends in Food Science and Technology, vol. 33, no. 2, pp. 110-123, 2013.

[23] S. J. Mcgrance, H. J. Cornell, and C. J. Rix, "A simple and rapid colorimetric method for the determination of amylose in starch products," Starch/Staerke, vol. 50, no. 4, pp. 158-163, 1998.

[24] H. Abral, M. M. Kadriadi, D. Handayani, E. Sugiarti, and A. N. Muslimin, "Characterization of disintegrated bacterial cellulose nanofibers/PVA bionanocomposites prepared via ultrasonication," International Journal of Biological Macromolecules, vol. 135, pp. 591-599, 2019.

[25] R. A. Ilyas, S. M. Sapuan, and M. R. Ishak, "Isolation and characterization of nanocrystalline cellulose from sugar palm fibres 
( _Arenga pinnata_ )," Carbohydrate Polymers, vol. 181, pp. 1038-1051, 2018.

[26] M. Asrofi, H. Abral, A. Kasim, and A. Pratoto, "XRD and FTIR studies of nanocrystalline cellulose from water hyacinth (Eichornia crassipes) fiber," Journal of Metastable and Nanocrystalline Materials, vol. 29, pp. 9-16, 2017.

[27] H. Abral, R. Soni Satria, M. Mahardika et al., "Comparative study of the physical and tensile properties of jicama (Pachyrhizus erosus) starch film prepared using three different methods," Starch/Staerke, vol. 71, pp. 1-9, 2019.

[28] H. Abral, A. Basri, F. Muhammad et al., "A simple method for improving the properties of the sago starch films prepared by using ultrasonication treatment," Food Hydrocolloids, vol. 93, pp. 276-283, 2019.

[29] A. Khan, R. A. Khan, S. Salmieri et al., "Mechanical and barrier properties of nanocrystalline cellulose reinforced chitosan based nanocomposite films," Carbohydrate Polymers, vol. 90, no. 4, pp. 1601-1608, 2012.

[30] H. Abral, A. S. Anugrah, F. Hafizulhaq, D. Handayani, E. Sugiarti, and A. N. Muslimin, "Effect of nanofibers fraction on properties of the starch based biocomposite prepared in various ultrasonic powers," International Journal of Biological Macromolecules, vol. 116, pp. 1214-1221, 2018.

[31] J. Epp, "X-ray diffraction (XRD) techniques for materials characterization," Elsevier Ltd, 2016.

[32] W. Cheng, J. Chen, D. Liu, X. Ye, and F. Ke, "Impact of ultrasonic treatment on properties of starch film-forming dispersion and the resulting films," Carbohydrate Polymers, vol. 81, no. 3, pp. 707-711, 2010.

[33] D. Merino, A. Y. Mansilla, T. J. Gutiérrez, C. A. Casalongué, and V. A. Alvarez, "Chitosan coated-phosphorylated starch films: water interaction, transparency and antibacterial properties," Reactive and Functional Polymers, vol. 131, pp. 445453, 2018.

[34] M. S. Goyat, S. Ray, and P. K. Ghosh, "Innovative application of ultrasonic mixing to produce homogeneously mixed nanoparticulate-epoxy composite of improved physical properties," Composites. Part A, Applied Science and Manufacturing, vol. 42, no. 10, pp. 1421-1431, 2011.

[35] H. Abral, M. H. Dalimunthe, J. Hartono et al., "Characterization of tapioca starch biopolymer composites reinforced with micro scale water hyacinth fibers," Starch/Staerke, vol. 70, no. 7-8, pp. 1-8, 2018.

[36] J. C. Martins da Costa, K. S. Lima Miki, A. da Silva Ramos, and B. E. Teixeira-Costa, "Development of biodegradable films based on purple yam starch/chitosan for food application," Heliyon, vol. 6, no. 4, p. e03718, 2020.

[37] J. Kim, Z. Cai, H. S. Lee, G. S. Choi, D. H. Lee, and C. Jo, "Preparation and characterization of a bacterial cellulose/chitosan composite for potential biomedical application," Journal of Polymer Research, vol. 18, no. 4, pp. 739-744, 2011.

[38] L. Y. Zheng and J. F. Zhu, "Study on antimicrobial activity of chitosan with different molecular weights," Carbohydrate Polymers, vol. 54, no. 4, pp. 527-530, 2003. 